\title{
Complex chemical interactions on thermo hydrolytic degradation of urea formaldehyde resins (UF-resins) in recycling UF-bonded boards
}

\author{
E. Roffael · H.-G. Hüster
}

Received: 2 March 2011 / Published online: 17 September 2011

(C) The Author(s) 2011. This article is published with open access at Springerlink.com

\begin{abstract}
Thermohydrolytic treatment of chips from UFbonded particleboards using the flask method technique at temperatures of about $103^{\circ} \mathrm{C}$ resulted in a notable increase in the $\mathrm{pH}$-value of aqueous absorption medium after a reaction period of $24 \mathrm{~h}$, most likely due to degradation of the UF-resin. This leads to neutralisation of the stronger formic acid to a much higher extent than acetic acid. Accordingly, the release of formic acid using the flask technique decreases to a much higher extent compared to that of acetic acid under the same conditions. The release of acetic acid could also be enhanced by possible deacetylation of the wood material induced by the hardener usually present in recovered UF-boards. This indicates that inextricably intertwined reactions unfold on hydrothermic degradation of UF-bonded particleboards.
\end{abstract}

\section{Chemische Wechselwirkungen bei dem thermohydrolytischen Abbau von UF-Harzen in Recyclingplatten}

Zusammenfassung Die thermohydrolytische Behandlung von UF-Holzspanplatten bei $103^{\circ} \mathrm{C}$ unter Verwendung des Flaschenverfahrens führt nach einer Reaktionsdauer von $24 \mathrm{~h}$ zu einer deutlichen Erhöhung des pH-Wertes. Dies äuBert sich in einer stärkeren Neutralisation von Ameisensäure im Vergleich zu Essigsäure. Entsprechend wird die Abgabemenge von freier Ameisensäure aus den Recyclingplatten

\section{E. Roffael $(\bowtie)$}

Georg-August-Universität Göttingen, Büsgenweg 1,

37077 Göttingen, Deutschland

e-mail: eroffae1@gwdg.de

H.-G. Hüster

Pfleiderer Industrie, Kunz Faserplattenwerk Baruth GmbH,

An der Birkenpfuhlheide 3, 15837 Baruth/Mark, Deutschland weitaus stärker reduziert als die der Essigsäure. Die Abgabe von Essigsäure aus Recyclingplatten könnte auch durch vermehrte Deacetylierung des Holzmaterials unter der Einwirkung von Härtern in Holzspanplatten forciert werden. Dies deutet darauf hin, dass chemische Reaktionen komplexer Natur während der thermohydrolytischen Behandlung von UF-Spanplatten stattfinden.

\section{Introduction}

In the wood-based panels industry, recycling of wood particle- and fibreboards is still an outstanding issue of increasing importance. Several processes have been developed for the recycling of UF-bonded particle- and fibreboards based on thermohydrolysis at temperatures ranging from 70-130 ${ }^{\circ} \mathrm{C}$ (DE-PS 42246 29, DE-PS 19509 152). A comprehensive critical survey of the different recycling techniques has been published by Roffael (1997), Hüster (1999), and Fleischer (2000). However, little work has been devoted to elucidate the complex chemical interactions between the degradation products of UF-resins in particle- and fibreboards and the release of volatile acids from recycled wood particles from UF-boards. This work investigates the impact of thermal hydrolytic degradation of UF-resins in UF-boards on the release of volatile organic acids, especially formic and acetic acid. For comparison wood particles prepared directly from wood were also subjected to thermohydrolysis under the same conditions and the emission of volatile acids thereof has also been evaluated. The liberation of volatile acids was correlated to the change in the $\mathrm{pH}$-value and buffering capacity of the released acids. 


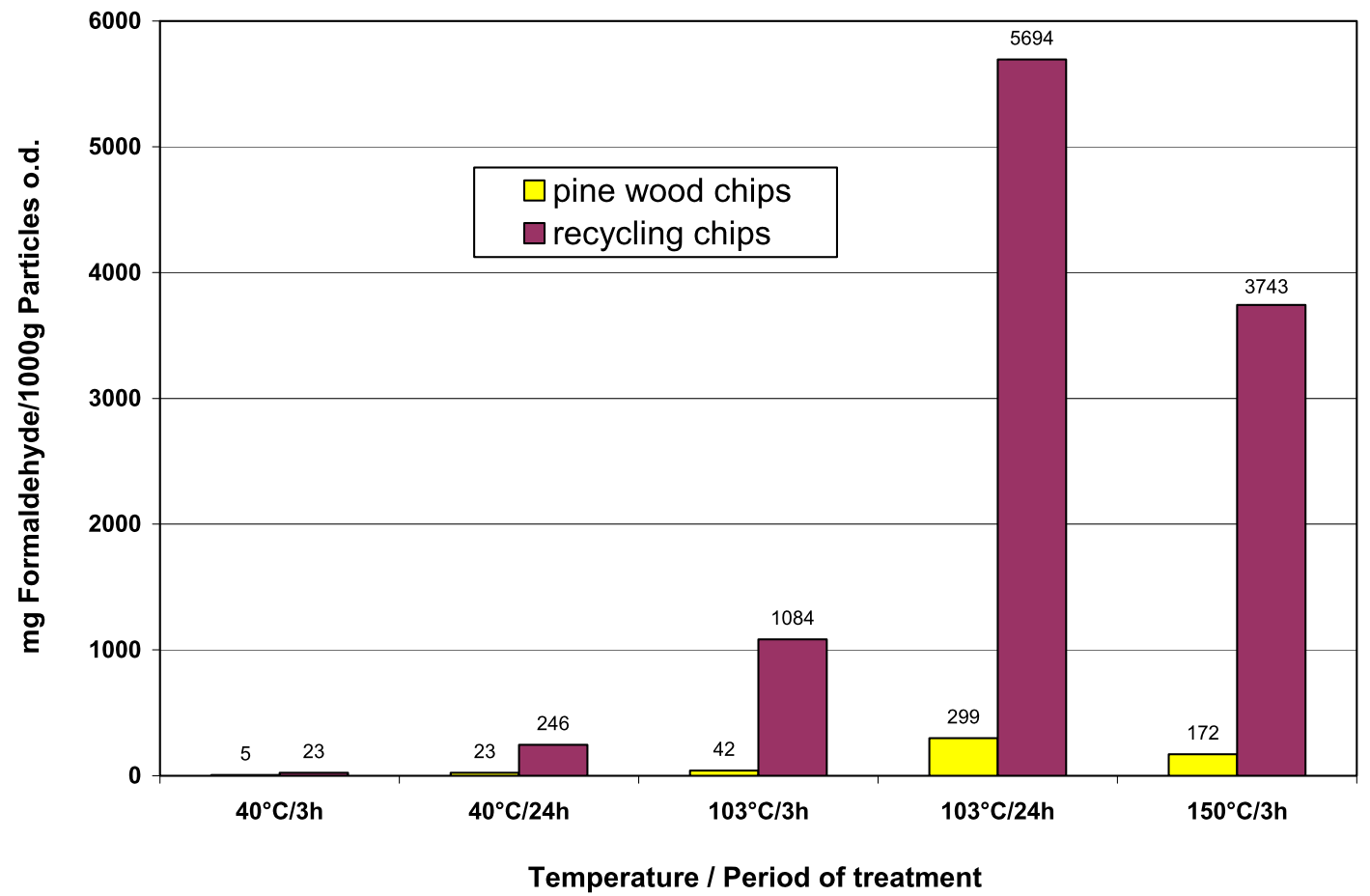

Fig. 1 Formaldehyde release from pine wood chips and recycling chips measured at different temperatures by the flask method (according to EN 717-3) (Hüster 1999)

Abb. 1 Formaldehydabgabe aus Kiefernholzspänen und Recyclingspänen, bestimmt nach unterschiedlicher Lagerungsdauer und bei verschiedenen Temperaturen mit Hilfe der Flaschenmethode gemäß EN 717-3 (Hüster 1999)

\section{Experimental work}

Wood particles prepared from virgin wood were used in the investigation along with particles of the same dimensions prepared from UF-bonded particleboards by thermohydrolytic degradation. The particles were tested for the release of formaldehyde and volatile organic acids using the flask method originally developed for measuring the formaldehyde release (Roffael 1975, EN 717-3) and later also for assessing the release of volatile acids (Roffael 1989). The released formaldehyde was photometrically determined using the acetyl acetone method according to EN 717-3. The volatile acids were assessed using ionic chromatography. Moreover, the changes in the $\mathrm{pH}$-value and in the buffering capacity of the absorption medium in the flask have also been evaluated. The buffering capacity has been determined by titration against $0.01 \mathrm{~N} \mathrm{NaOH}$ solution.

\section{Results and discussion}

The results of the formaldehyde emission, measured by using the flask method at different temperatures and reaction times are depicted in Fig. 1 for particles from virgin wood. The results indicate that the formaldehyde emanation increases drastically with raising the temperature from $40^{\circ} \mathrm{C}$ over $103^{\circ} \mathrm{C}$ to $150^{\circ} \mathrm{C}$ for the same reaction time $(3 \mathrm{~h})$ from $5 \mathrm{mg} / 1000 \mathrm{~g}$ particles at $40^{\circ} \mathrm{C}$ to $172 \mathrm{mg} / 1000 \mathrm{~g}$ particles at $150^{\circ} \mathrm{C}$. Extending the reaction period from $3 \mathrm{~h}$ to $24 \mathrm{~h}\left(\right.$ at $\left.103^{\circ} \mathrm{C}\right)$ induces an enormous change in the formaldehyde release from $23 \mathrm{mg} / 1000 \mathrm{~g}$ particles at $40^{\circ} \mathrm{C}$ to $299 \mathrm{mg} / 1000 \mathrm{~g}$ particles at $103^{\circ} \mathrm{C}$. At the same time the $\mathrm{pH}$-value of the absorption medium in the flask decreases from 5.1 after a reaction period of $3 \mathrm{~h}$ at $40^{\circ} \mathrm{C}$ to 4.0 after the same period at $103^{\circ} \mathrm{C}$ (Fig. 2).

The $\mathrm{pH}$-value of the absorption medium in the flask decreased continuously with extending the reaction time at the same temperature or by increasing the temperature at the same reaction time (Fig. 2). The $\mathrm{pH}$-value declined, e.g., from $5.1\left(3 \mathrm{~h}, 40^{\circ} \mathrm{C}\right)$ to $3.6\left(3 \mathrm{~h}, 150^{\circ} \mathrm{C}\right)$. In a parallel manner the alkaline buffering capacity of the absorption aqueous solution increased from $40^{\circ} \mathrm{C}$ to $103^{\circ} \mathrm{C}$ indicating rising acidity of the medium (Fig 3). In Figs. 4 and 5, the amount of released formic (Fig. 4) and acetic acids (Fig. 5) was determined by ionic chromatography in the aqueous absorption medium. As the results reveal, both the amount of acetic and formic acid increase after thermohydrolytic treatment of untreated wood chips. Keeping the reaction period at $3 \mathrm{~h}$, increasing temperature drives the amount of releasable formic acid to even higher values than the amount of acetic acid released at the same reaction period. However, increasing the reaction period to $24 \mathrm{~h}$ at $103^{\circ} \mathrm{C}$ ushers in more release of 


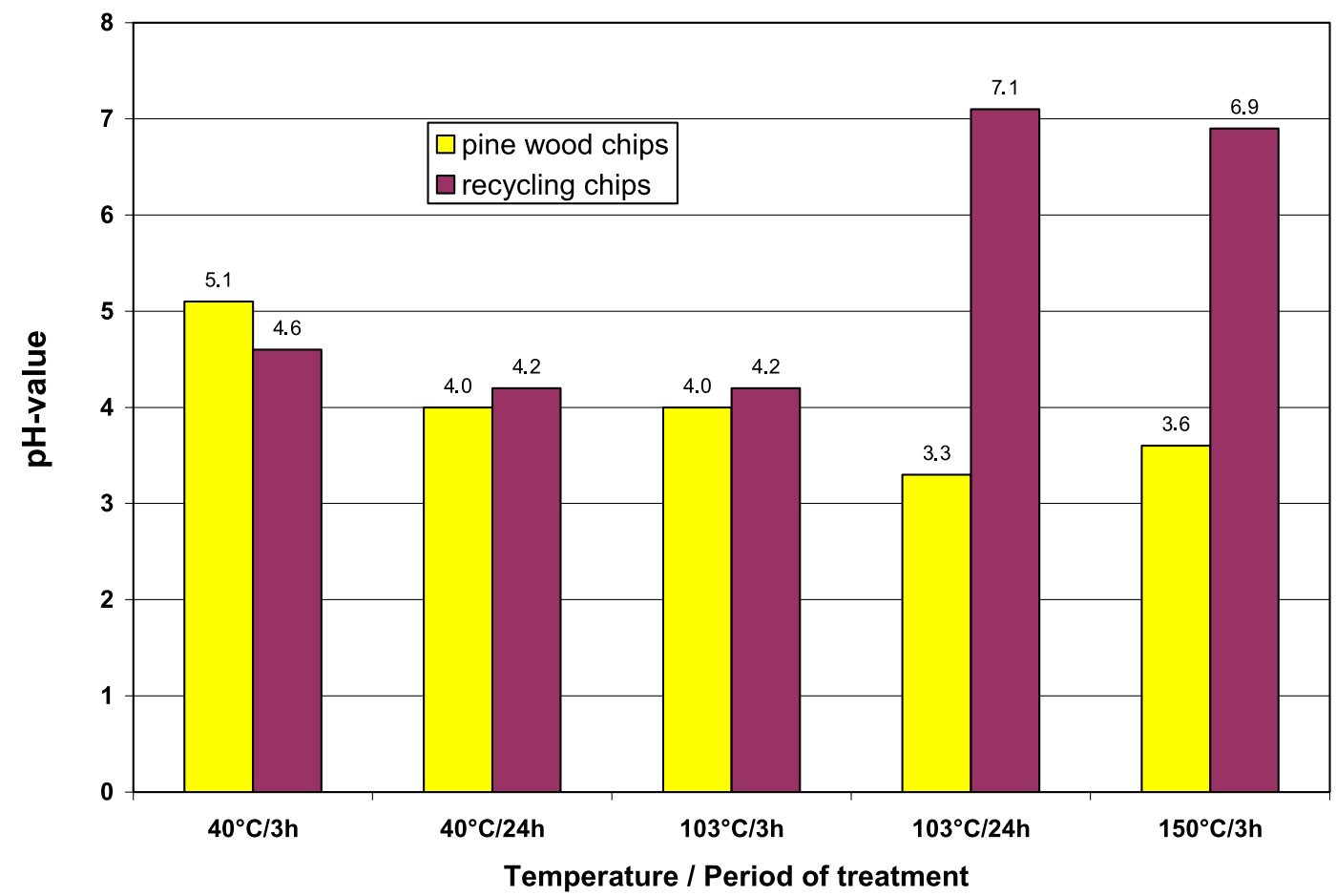

Fig. 2 pH-value of the absorption liquid from pine wood chips and recycling chips measured at different temperatures by the flask method (according to EN 717-3) (Hüster 1999)

Abb. 2 pH-Wert der Absorptionsflüssigkeit im Flaschentest (EN 717-3), ermittelt für Kiefernholzspäne und Recyclingspäne nach unterschiedlicher Lagerungsdauer bei verschiedenen Temperaturen (Hüster 1999)

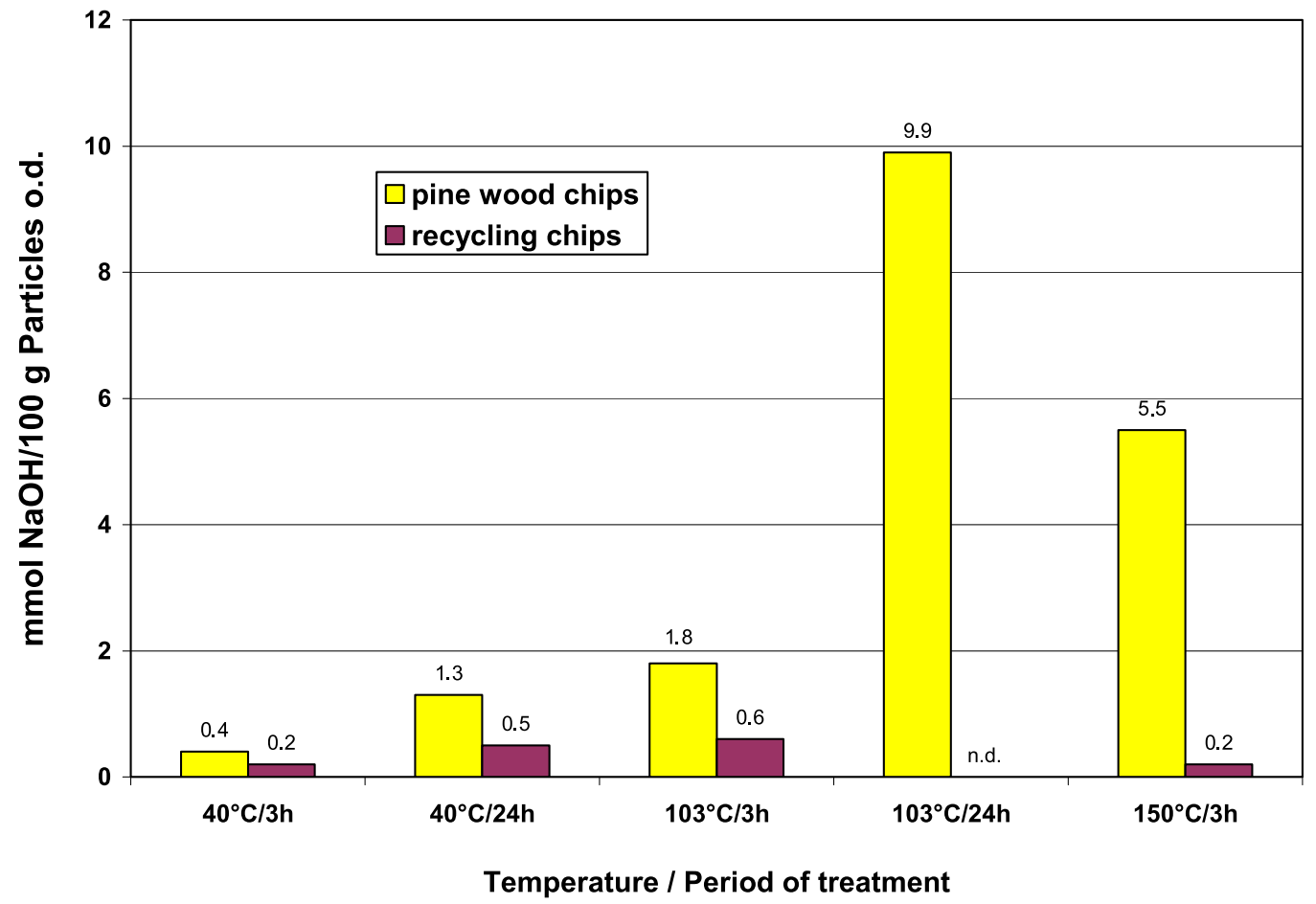

Fig. 3 Buffering capacity of the absorption liquid from pine wood chips and recycling chips measured at different temperatures by the flask method (according to EN 717-3) (Hüster 1999) (n.d. = not determined)

Abb. 3 Pufferkapazität der Absorptionsflüssigkeit im Flaschentest (EN 717-3), ermittelt für Kiefernholzspäne und Recyclingspäne nach unterschiedlicher Lagerungsdauer bei verschiedenen Temperaturen (Hüster 1999) (n.d. = nicht bestimmt) 


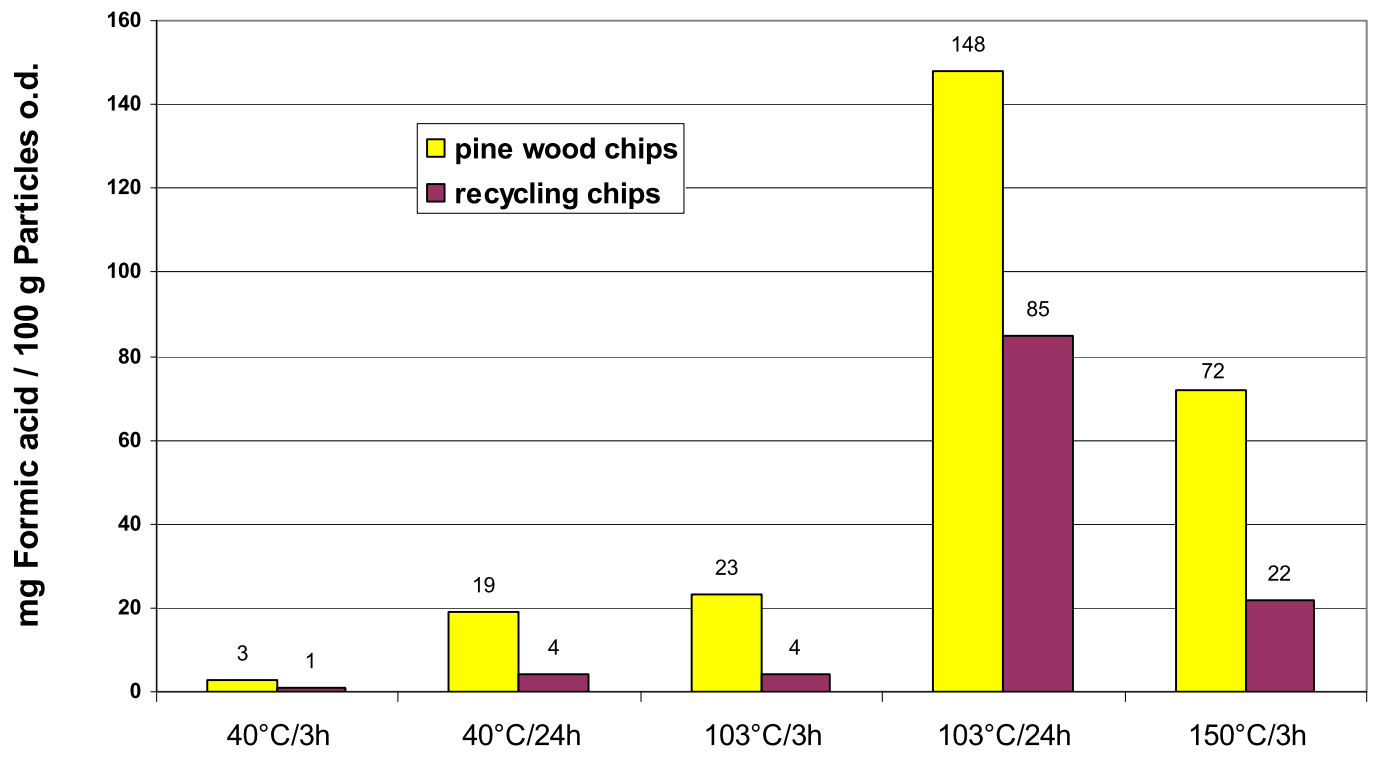

Temperature / Period of treatment

Fig. 4 Formic acid release from pine wood chips and recycling chips measured at different temperatures by the flask method (according to EN 717-3) (Hüster 1999)

Abb. 4 Abgabe von Ameisensäure aus Kiefernholzspänen und Recyclingspänen, ermittelt nach dem Flaschentest (EN 717-3) nach unterschiedlicher Lagerungsdauer bei verschiedenen Temperaturen (Hüster 1999)

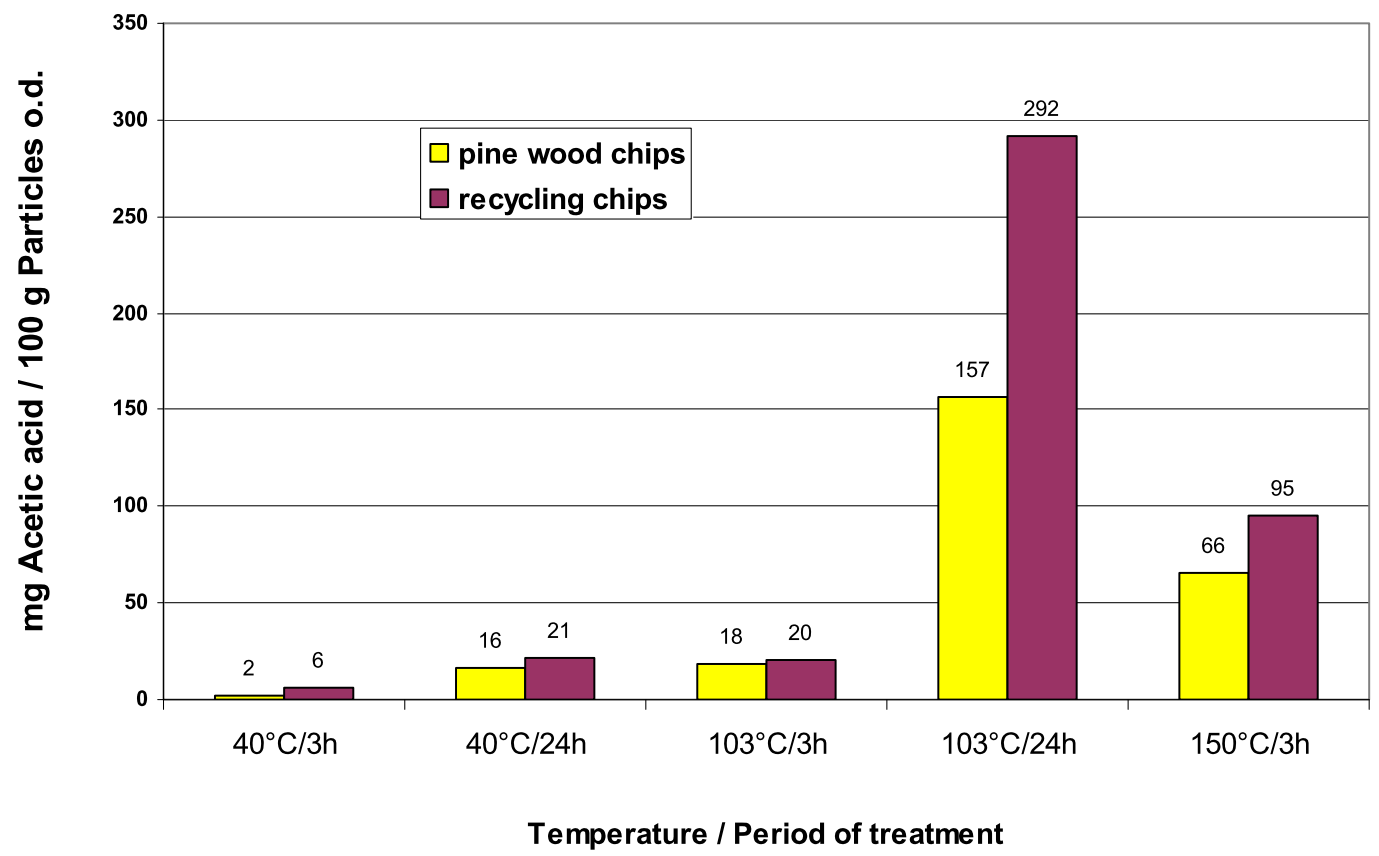

Fig. 5 Acetic acid release from pine wood chips and recycling chips measured at different temperatures by the flask method (according to EN 717-3) (Hüster 1999)

Abb. 5 Abgabe von Essigsäure aus Kiefernholzspänen und Recyclingspänen, ermittelt nach dem Flaschentest (EN 717-3) nach unterschiedlicher Lagerungsdauer bei verschiedenen Temperaturen (Hüster 1999) 
acetic acid compared to formic acid, which may be due to increased deacetylation of wood at high temperatures (Egner 1951).

The release of formaldehyde from recycled particles (Fig. 1) is, as expected, much higher than that from untreated particles. The difference between the two types of particles (from virgin wood and from particleboards) increases dramatically with increasing testing temperature (Fig. 1).

In case of recycling chips the change in the $\mathrm{pH}$-value shows a peculiar behaviour; it decreases slightly on keeping the reaction period at $3 \mathrm{~h}$ up to $103^{\circ} \mathrm{C}$ (Fig. 2). However, increasing the reaction period at $103^{\circ} \mathrm{C}$ to $24 \mathrm{~h}$ shifts significantly the $\mathrm{pH}$-value to higher values indicating possible degradation in the UF-resin at high temperatures (at $103^{\circ} \mathrm{C}$ and above). Thermohydrolytic degradation of UFresins may be catalysed by acids originating from wood (acetic, formic acid) as well as other acids emerging from the usually used hardeners like ammonium sulphate and ammonium nitrate, which may lower the activation energy needed to disrupt the structure of cross-linked UF-resins leading to the formation of urea and urea formaldehyde prepolymers (Myers 1983).

In the light of the obtained results, it becomes understandable that, after leaving the cooling wheal in the factory, UF-boards have to be cooled to temperatures less than $70^{\circ} \mathrm{C}$ to avoid hydrolysis and formation of urea and urea prepolymers, which may lead to a decrease in internal bond strength. The same trend shows the buffering capacity (Fig. 3); it increased steadily till $103^{\circ} \mathrm{C}$ at a reaction time of $3 \mathrm{~h}$. On extending the reaction time to $24 \mathrm{~h}$ at $103^{\circ} \mathrm{C}$ a remarkable drop in the buffering capacity unfolds indicating severe degradation of UF-resin under such conditions, which ushers in a significant decline in the acidity ( $\mathrm{pH}$-value, buffering capacity) of the absorption medium (Franke 1999).

As far as the release of volatile acids from recovered particles is concerned a quintessential phenomenon becomes obvious (Figs. 4, 5): The release of formic acid is suppressed over the entire temperature range in comparison to its release in case of untreated particles (Fig. 4). In contrast, the emanation of acetic acid soars to higher values. After a reaction period of $24 \mathrm{~h}$ at $103^{\circ} \mathrm{C}$ the amount of liberated formic acid from recovered particles enormously decreased compared to the values obtained from untreated pine wood particles $(148 \mathrm{mg} / 100 \mathrm{~g}$ particles versus $85 \mathrm{mg} / 100 \mathrm{~g}$ board). In comparison, however, the liberation of acetic acid from recycling boards (Fig. 5) increased by more than $90 \%$ under the same reaction conditions $(157 \mathrm{mg} / 100 \mathrm{~g}$ versus $292 \mathrm{mg} / 100 \mathrm{~g}$ at $\left.103^{\circ} \mathrm{C}, 24 \mathrm{~h}\right)$. The same conclusion can be drawn at $150^{\circ} \mathrm{C} / 3 \mathrm{~h}$. Also, under such conditions the release of formic acid is lagging behind that from untreated particles.
The reason for the deviating behaviour of recycling chips can be explained as follows: At $103^{\circ} \mathrm{C}$ an increase in the $\mathrm{pH}$-value in recycling chips unfolds due to the emanation of ammonia and other alkaline reacting degradation products from recycling boards inducing a shift in the $\mathrm{pH}$-value (Franke 1999). Ammonia (e.g.), as a degradation product of UF-resins, reacts preferably with formic acid due to its higher acidity (pKa 3.7) compared to acetic acid (pKa 4.8) under the formation of ammonium formate. The equilibrium reaction can be presented by the following equation:

$$
\begin{aligned}
& \mathrm{HCOOH}+\mathrm{NH}_{4} \mathrm{OH} \rightleftarrows \mathrm{HCOONH}_{4}+\mathrm{H}_{2} \mathrm{O} \\
& \mathrm{CH}_{3} \mathrm{COOH}+\mathrm{NH}_{4} \mathrm{OH} \leftrightarrows \mathrm{CH}_{3} \mathrm{COONH}_{4}+\mathrm{H}_{2} \mathrm{O}
\end{aligned}
$$

In the equilibrium state more free acetic acid is present compared to formic acid. Accordingly, more free and steam distillable acetic acid can be liberated under the above described conditions. The increase of acetic acid release from recycled boards may also be due to the attack of mineral acids formed from the used hardeners by hydrolysis (e.g. $\mathrm{H}_{2} \mathrm{SO}_{4}$ from $\left.\left(\mathrm{NH}_{4}\right)_{2} \mathrm{SO}_{4}\right)$ on the wood substance in recovered particleboards leading to more degradation of acetyl groups.

Open Access This article is distributed under the terms of the Creative Commons Attribution Noncommercial License which permits any noncommercial use, distribution, and reproduction in any medium, provided the original author(s) and source are credited.

\section{References}

Egner K (1951) Zur Trocknung von Hölzern bei Temperaturen über $100^{\circ} \mathrm{C}$. Holz Roh- Werkst 9:84-97

Fleischer O (2000) Untersuchungen zur Mobilisierung von Formaldehyd und anderen ökologisch relevanten Stoffen beim thermohydrolytischen Recycling von Harnstoff-Formaldehyd-Harzgebundenen Spanplatten und Altmöbeln. Dissertation, Technische Universität Braunschweig. Verlag Mensch und Buch, Berlin

Franke R (1999) Zum Recycling von Holzspanplatten und mitteldichten Faserplatten. Dissertation, Georg-August-Universität Göttingen

Hüster H-G (1999) Beiträge zum Recycling von harnstofformaldehydharz-gebundenen Holzspanplatten unter besonderer Berücksichtigung des Einsatzes von Tanninen. Dissertation, Georg-AugustUniversität Göttingen. Shaker Verlag, Aachen

Myers G (1983) Use of acid scavengers to improve durability of acid catalysed adhesive wood bonds. For Prod J 33(4):49-57

Roffael E (1975) Messung der Formaldehydabgabe: Praxisnahe Methode zur Ermittlung der Formaldehydabgabe harnstoffharzgebundener Spanplatten für das Bauwesen. Holz-Zentralblatt 101(111):1403-1404

Roffael E (1989) Abgabe von flüchtigen organischen Säuren aus Holzspänen und Holzspanplatten. Holz Roh- Werkst 47:447-452

Roffael E (1997) Stoffliche Verwertung von Holzwerkstoffen. Adhäsion 41:24-27 